\title{
Jere Jareb (3. svibnja 1922. - 21. studenoga 2017.)
}

Dana 21. studenoga 2017. u Charlottesvilleu (Virginia) u Sjedinjenim Američkim Državama preminuo je u dobi od 95 godina istaknuti hrvatski povjesničar i dugogodišnji hrvatski politički emigrant dr. Jere Jareb.

Rođen je u mjestu Prvić Šepurine na otoku Prviću u šibenskoj okolici 3. svibnja 1922. godine. Rano je pokazao zanimanje za hrvatsku povijest, a svoje prve (školske) radove povijesne tematike pisao je kao učenik šibenske gimnazije prije Drugoga svjetskog rata. Dolazak rata zatekao ga je u Šibeniku, a iz tada anektirane "talijanske" Dalmacije u rujnu 1941. prešao je u Zagreb, gdje je upisao studij prava. Unatoč tome, i dalje ga je zanimala hrvatska povijest, o čemu govori i više članaka povijesne tematike koje je tijekom rata objavio u različitim časopisima. Zdravstveno stanje oslobodilo ga je vojne službe, a uz studij prava bavio se novinarskim i publicističkim radom. Kraj rata potaknuo je njegov odlazak iz domovine, pa je nakon duljega povlačenja prema zapadu uspio doći u Klagenfurt, u kojem je proveo nekoliko sljedećih godina. Otprije prisutna bolest i nedaće višednevnoga povlačenja utjecale su na njegovo zdravstveno stanje, a naposljetku mu je bila amputirana desna noga. Kako je poslije znao govoriti, to ga je na neki način predodredilo da se posveti karijeri povjesničara i sveučilišnoga nastavnika. Došavši naime 1952. zalaganjem svojega oca, prijeratnoga iseljenika u tu zemlju, u Sjedinjene Američke Države, postavilo se pitanje njegova daljnjega životnog puta. S obzirom na invalidnost, u obzir nije dolazio nikakav fizički posao, pa mu je omogućen nastavak u Zagrebu naglo prekinutog studija. Upisavši studije na čuvenom Sveučilištu Columbia u New Yorku, u kojem je tada živio, Jere Jareb ubrzo se posvetio istraživanju jadranskoga pitanja nakon Prvoga svjetskog rata. Na tu je temu naposljetku i doktorirao 1964. godine. Nedugo po dolasku u New York uključio se u hrvatsko emigrantsko intelektualno djelovanje. Već 1953. bio je jedan od osnivača Hrvatske akademije Amerike (Croatian Academy of America), a iste je godine postao povjerenikom Hrvatske revije Vinka Nikolića. Na stranicama akademijina časopisa Journal of Croatian Studies (izlazi od 1960.) i posebice Hrvatske revije u sljedećim je desetljećima svojega emigrantskog djelovanja objavio niz radova trajne vrijednosti, pri čemu je posebnu pozornost posvetio objavljivanju izvora za suvremenu hrvatsku povijest. Suradnja u Hrvatskoj reviji odgovorna je i za izlazak njegove prve knjige, Pola stoljeća hrvatske politike (1960.), također u nakladi knjižnice toga časopisa. Utemeljena na radu koji je prvobitno objavljen u Hrvatskoj reviji 1959., knjiga je bila studija koja je kritički pristupila sjećanjima dr. Vladka Mačeka objavljenim u Sjedinjenim Američkim Državama 1957. pod naslovom In the Struggle for Freedom. Jere Jareb nije tek kritički vrednovao Mačekova stajališta, nego je i na temelju vlastitih istraživanja i dostupnih izvora napisao do tada jedinstven pregled suvremene hrvatske povijesti od 1895. do 1945. godine. Iako je od izdanja te knjige prošlo gotovo šest desetljeća, ona je i danas vrijedno i za istraživače toga razdoblja nezaobilazno štivo. 
Jere Jareb u New Yorku je živio i stvarao do 1966., a u tom je gradu zasnovao i obitelj. Te je godine prešao na tada maleni Saint Francis College u Lorettu (Pennsylvania), gdje je živio sve do prije nekoliko godina.

Slom komunističkoga sustava u Hrvatskoj i uspostava suvremene hrvatske države najavili su njegov bar privremeni boravak u domovini. U jeku Domovinskoga rata uspostavio je kontakte s tadašnjim Institutom za suvremenu povijest i njegovim tadašnjim ravnateljem Mirkom Valentićem, a prvi plod te suradnje bilo je drugo izdanje knjige Pola stoljeća hrvatske politike 1995. u izdanju Instituta i s novim predgovorom iz Jerina pera, u kojem je progovorio o metodologiji i izvorima za istraživanja suvremene hrvatske povijesti, posebice povijesti Nezavisne Države Hrvatske. Nedugo po izlasku knjige, koji dan više od pola stoljeća nakon što je početkom svibnja 1945. napustio domovinu, u svibnju 1995. Jere Jareb ponovno je bio na hrvatskom tlu. Iako se nije trajno preselio u domovinu, sljedećih je osam godina svake godine zajedno sa suprugom Olgom više od pola godine provodio u domovini, gdje se mogao posvetiti svojoj najvećoj strasti - istraživanju suvremene hrvatske povijesti. Mnogi istraživači i danas pamte njegove dugotrajne boravke u čitaonici Hrvatskoga državnog arhiva, a posljedak njegova rada prvenstveno su dvije važne zbirke dokumenata, obje u nakladi Hrvatskoga instituta za povijest, koje je obogatio vrijednim uvodnim studijama. Najprije je 1997. objavio zbirku Zlato i novac Nezavisne Države Hrvatske izneseni u inozemstvo 1944. i 1945., kojom je na temelju dostupnoga izvornoga gradiva opovrgnuo tada prisutne bajkovite, često bizarne i zlonamjerne tvrdnje o takozvanom ustaškom zlatu. Godine 2001. objavljena je pak zbirka Državno gospodarstveno povjerenstvo Nezavisne Države Hrvatske od kolovoza 1941. do travnja 1945. godine. U međuvremenu je objavio niz radova u različitim časopisima u domovini, prije svega u Časopisu za suvremenu povijest i Hrvatskoj reviji. Radio je i na monografiji o državnoj vladi Nezavisne Države Hrvatske, no ona nije objavljena. Tijekom boravaka u domovini bio je blizak suradnik Hrvatskoga instituta za povijest. Institutu je ostavio i svoju vrijednu knjižnicu stvaranu desetljećima, koja sadržava brojna vrijedna, pa i rijetka izdanja, posebice hrvatska emigrantska izdanja. Bogatu zbirku novina, uglavnom hrvatskoga i nešto srpskoga emigrantskog tiska, pohranio je u Nacionalnoj i sveučilišnoj knjižnici, a dokumentarnu ostavštinu u Hrvatskom državnom arhivu.

Nakon 2003., djelomice i zbog zdravstvenih razloga, Jere Jareb nije više mogao dolaziti u domovinu, iako je i nakon toga objavio nekoliko radova $\mathrm{u}$ hrvatskim časopisima.

Od tada je boravio u svojem domu u Lorettu, živo prateći rad hrvatske historiografije, a prije nekoliko godina supruga Olga i on preselili su se u Charlottesville, gdje je i našao svoj vječni mir.

Mario Jareb 